
SUSUNAN DEWAN REDAKSI

“JURNAL NASIONAL KOMPUTASI DAN TEKNOLOGI INFORMASI (JNKTI)"

\author{
Penanggung Jawab \\ Muhammad Fadhli, S.Kom, M.Kom \\ Ketua Dewan Editor \\ Zulfan, ST, MT \\ Editor Pelaksana \\ Munawir, ST, MT \\ Baihaqi, ST, MT \\ Sekretaris \\ Yeni Yanti, ST, MT \\ Mitra Bestari \\ Prof. Dr. Ir. Yuwaldi Away, M.Sc \\ Dr. Taufiq A. Gani, S.Kom, M.Eng.Sc \\ Dr. Melinda, ST, M.Sc \\ Layout \\ Eka Novendra, ST \\ Penerbit \\ Program Studi Teknik Informatika \\ Universitas Serambi Mekkah \\ Alamat Penerbit
}

Gedung H Fakultas Teknik Universitas Serambi Mekkah

Jl. T. Imum Lueng Bata, Telp. (0651)26160 Batoh - Banda Aceh 


\section{SINOPSIS}

Jurnal Nasional Komputasi dan Teknologi Informasi (JNKTI) merupakan jurnal ilmiah nasional yang diterbitkan oleh Program Studi Teknik Informatika Universitas Serambi Mekkah yang mempublikasikan artikel-artikel ilmiah dalam bidang komputasi dan teknologi informasi.Jurnal ini terbit sebanyak 2 (dua) kali dalam 1 (satu) tahun yaitu pada Bulan April dan Oktober. Bidang-bidang fokus penelitian yang akan dipublikasi dalam jurnal ini antara lain :

- Bidang Rekayasa Perangkat Lunak

- Bidang Jaringan Komputer

- Bidang Multimedia dan Pengolahan Citra Digital

- Bidang Komputasi

- Multidisiplin ilmu lainnya yang relevan 
DAFTAR ISI

JNKTI VOL.2 NO.1, APRIL 2019

Studi Simulasi Aerodinamika Airfoil dan Prediksi

$1-8$

Performa Picth Tetap Turbin Angin Poros Tegak (Darrieus)

terhadap Output Power untuk Aplikasi Kecepatan Angin Rendah

Wahyu Priyanto ${ }^{1}$, Ira Devi Sara ${ }^{2}$, Rakhmad Syafutra Lubis ${ }^{3}$

Analisis Performansi Video Streaming Dengan Menggunakan

$9-12$

Protokol RTSP Pada Jaringan IEEE 802.11n

Rahmad Rizki ${ }^{1}$, Rizal Munadi ${ }^{2}$, Syahrial $^{2}$

Pengaruh Heatsink Terhadap Kinerja Modul Surya

$13-18$

T. Mizan Sya'rani D. ${ }^{1 *}$, Ira Devi Sara ${ }^{2}$, dan Laina Hilma Sari ${ }^{3}$

Penentuan Tingkat Penyebaran Ikan Berdasarkan Citra

Suhu Permukaan Laut Di Perairan Laut Kabupaten Aceh Jaya

Menggunakan Satelit Aqua Modis

Naziran ${ }^{1}$, Rizal Munadi ${ }^{2}$, Muchlisin ${ }^{2}$

Studi Pengaruh Hibridisasi Seleksi Roullete Wheel Dengan $26-30$

Tournament Selection Menggunakan Algoritma Berevolusi Pada TSP

Cut lilis Setiawati ${ }^{1}$, Taufiq Abdul Gani ${ }^{2}$, Yuwaldi Away ${ }^{2}$

Audit Dan Optimasi Energi Listrik Pada Bangunan Kampus $31-37$

Menggunakan Metode Algoritma Genetika

Samsuddin $^{1}$, Suriadi ${ }^{2}$, Yuwaldi Away ${ }^{3}$

Aplikasi Histogram Discrete Cosine Transform (DCT) Untuk $38-42$

Sistem Temu Kembali Citra Termal Berbasis Konten

Faridah $^{1}$, Khairul Munadi ${ }^{2}$, Fitri Arnia ${ }^{3}$

Pengujian Algoritma Artificial Neural Network (ANN) $43-47$

Untuk Prediksi Kecepatan Angin

Syukri $^{1}$, Samsuddin ${ }^{2}$

Penerapan Information Retrieval Menggunakan Pemodelan $48-54$

Topik Pada Deskripsi Portal Multimedia

Indra Gita Anugrah ${ }^{1}$ dan Harunur Rosyid ${ }^{2}$

Analisa Steganografi untuk Citra Bewarna (RGB)

Menggunakan Metode Less Significant Bit (LSB)

Raihan Islamadina $^{1}$, Baihaqi $^{2}$, dan Mauzar sulistriadi ${ }^{3}$ 


\title{
Studi Simulasi Aerodinamika Airfoil dan Prediksi Performa Picth Tetap Turbin Angin Poros Tegak (Darrieus) terhadap Output Power untuk Aplikasi Kecepatan Angin Rendah
}

\author{
Wahyu Priyanto ${ }^{1}$, Ira Devi Sara ${ }^{2}$, Rakhmad Syafutra Lubis ${ }^{3}$ \\ 1,2.3 Magister Teknik Elektro, Fakultas Teknik, Universitas Syiah Kuala \\ Jl. Tgk. Syech Abdulrauf No. 7, Darussalam Banda Aceh 23111 \\ Email: wahyupiu@gmail.com
}

\begin{abstract}
Abstrak - Turbin angin sumbu vertikal adalah turbin angin yang sangat efektif di terapkan pada wilayah perkotaan. Integrasi dengan infrastuktur bangunan kota, turbin angin ini sangat memungkinkan untuk bersinergi, serta memiliki respon yang lebih baik dalam turbulensi aliran yang umum di wilayah perkotaan. Artikel ini memberikan kontribusi untuk pengembangan aerodinamis rotor turbin dalam mempelajari turbin angin sumbu vertikal, dengan metode Double Multiple Stream Tube (DMS). Metode DMS ini menggunakan software Qblade untuk mengembangkan serta memprediksi picth yang digunakan secara tetap pada turbin angin vertikal sekala kecil di Banda Aceh dengan koordinat latitude 5.58 $8^{\circ}$ longitude $95.37^{\circ}$.Pengembangan mengunakan NACA airfoil 4418 konvensional dan 4418 yang telah di modifikasi bagian trillingnya, telah terbukti dapat meningkatkan nilai koefisien daya $(\mathrm{Cp})$ yang mampu bekerja pada tip speed rasio yang rendah serta lebih efesien dalam pengunaan turbin angin jenis Darrieus poros tegak,dengan mengubah serta menghilangkan pada bagian trilling $10^{\circ}$ terbukti mampu meningkatkan nilai koefisien daya (Cp) 26\% dengan nilai puncak $43 \%$ dari sebelumnya (bentuk airfoil konvensional) dengan nilai Cp 19\% dengan nilai puncak 37\% yang mampu bekerja pada rasio tip yang relatif rendah dengan nilai TSR 1.9 dengan meningkatnya nilai Cp maka efesiensi maksimum dapat didekati.Dengan menggunakan airfoil ini untuk lebih mengutamakan gaya lift sebagai kelebihannya, yang mampu bekerja pada kecepatan angin yang relativ rendah.
\end{abstract}

Kata Kunci : Turbin Angin, Darrieus, poros tegak, koefisien daya, Tip Speed rasio rendah

\section{Pendahuluan}

Saat ini energy angin dan matahari telah banyak di terapkan sebagai penghasil energi secara luas untuk pembangkit tenaga listrik pada sekala utilitas. Menggunakan desain yang lebih inovatif sangat penting dalam perannya untuk lebih banyak menyerap sumber energi Kinetik [1]. Diantara sumber energi yang terbarukan, energi angin adalah sumber energi yang paling menjanjikan untuk menghasilkan energi listrik dan digunakan secara luas untuk berbagai kebutuhan.

Biasanya turbin angin di bagi menjadi dua tipe utama yang berbeda yaitu turbin angin sumbu vertical atau lebih dikenal dengan (VAWT) dan turbin angin sumbu horizontal (HAWT). Kedua tipe turbin angin tersebut memilliki karakter turbin yang berbeda, bersama dengan kelebihan dan kekurangan masingmasing sebagai turbin angin. Sumber energi kinetik yang bersumber dari angin yang kemudian ditangkap oleh turbin angin di hitung dengan mengalikan kecepatan udara $(\mathrm{v}(\mathrm{m} / \mathrm{s}))$ dan setengah dari densitas udara $\left(\rho\left(\mathrm{kg} / \mathrm{cm}^{3}\right)\right)$.

Turbin angin kecil umumnya berkisar $10 \mathrm{KW}$ atau kurang, system turbin angin terdiri dari turbin angin, menara (tower), pengontrol charge (controller), inverter dan baterai serta generator.
Untuk kebutuhan desain turbin angin, data merujuk pada NASA POWER data access kota Banda Aceh yang memiliki kecepatan angin rata-rata $4.35 \mathrm{~m} / \mathrm{s}$. Data tersebut merupakan data rata-rata 3 tahun (2015-2017), yang disajikan pada gambar 1 dan gambar 2 bahwa potensi untuk pembangkit listrik tenaga angin sangat memungkinkan. Namun tidak semua jenis turbin angin dapat efektif dengan kondisi angin dengan kecepatan rendah. Potensi energi angin secara keseluruhan dapat dilihat secara keseluhan pada wilayah ini Indonesia dan secara khusus pada wilayah kota Banda Aceh seperti yang terlihat pada resource map pada gambar 2 dan gambar 3.

Data cuaca yang di tunjukkan oleh NASA POWER (Prediction of worldwide energy resource) pada kota Banda Aceh koordinat latitude 5.58 ${ }^{\circ}$ longitude $95.36^{\circ}$ yang memiliki rata-rata kecepatan angin yang relatif rendah dapat diamati pada Gambar 1.2, Pemanfaatan potensi angin yang sesuai dengan daerah kota Banda Aceh. 


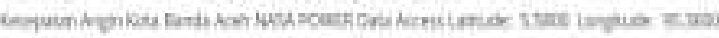

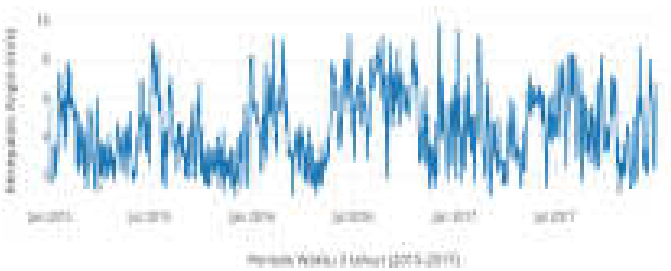

Gambar 1. Grafik Data kecepatan angin NASA POWER data access Kota Banda Aceh tahun 20152017[2]

Tabel 1. Data kecepatan angin rata-rata kota Banda Aceh koordinat latitude $5.58^{\circ}$ longitude $95.36^{\circ}$

\begin{tabular}{|c|c|c|c|c|c|}
\hline Month & $\begin{array}{l}\text { Air } \\
\text { temperatu } \\
\text { re }\end{array}$ & $\begin{array}{l}\text { NAS } \\
\text { A } \\
\text { Powe } \\
\text { r data } \\
2017\end{array}$ & $\begin{array}{l}\text { NAS } \\
\text { A } \\
\text { Powe } \\
\text { r data } \\
2016\end{array}$ & $\begin{array}{l}\text { NAS } \\
\text { A } \\
\text { Powe } \\
\text { r data } \\
2015\end{array}$ & $\begin{array}{l}\text { Earth } \\
\text { temperatu } \\
\text { re }\end{array}$ \\
\hline & ${ }^{\circ} \mathrm{C}$ & $\mathrm{m} / \mathrm{s}$ & $\mathrm{m} / \mathrm{s}$ & $\mathrm{m} / \mathrm{s}$ & ${ }^{\circ} \mathrm{C}$ \\
\hline January & 26.2 & 4.53 & 4.79 & 4.41 & 27.9 \\
\hline February & 26.2 & 4.59 & 5.9 & 5.11 & 28.3 \\
\hline March & 26.3 & 2.93 & 3.60 & 3.30 & 28.8 \\
\hline April & 26.6 & 5.80 & 5.55 & 2.5 & 29.1 \\
\hline May & 27.1 & 3.45 & 2.46 & 2.71 & 29.2 \\
\hline June & 27.2 & 4.80 & 5.02 & 3.65 & 29.1 \\
\hline July & 27 & 5.94 & 5.29 & 5.37 & 28.8 \\
\hline August & 26.8 & 6.74 & 6.01 & 4.2 & 28.6 \\
\hline $\begin{array}{l}\text { Septemb } \\
\text { er }\end{array}$ & 26.4 & 4.98 & 7.13 & 4.29 & 28.4 \\
\hline October & 26.1 & 4.69 & 6.17 & 3.62 & 28.3 \\
\hline $\begin{array}{l}\text { Novemb } \\
\text { er }\end{array}$ & 25.9 & 3.72 & 4.64 & 2.42 & 28.1 \\
\hline $\begin{array}{l}\text { Decemb } \\
\text { er }\end{array}$ & 26.1 & 4.60 & 4.52 & 3.65 & 27.9 \\
\hline Average & 26.5 & 4.4 & 4.9 & 3.7 & 28.5 \\
\hline
\end{tabular}

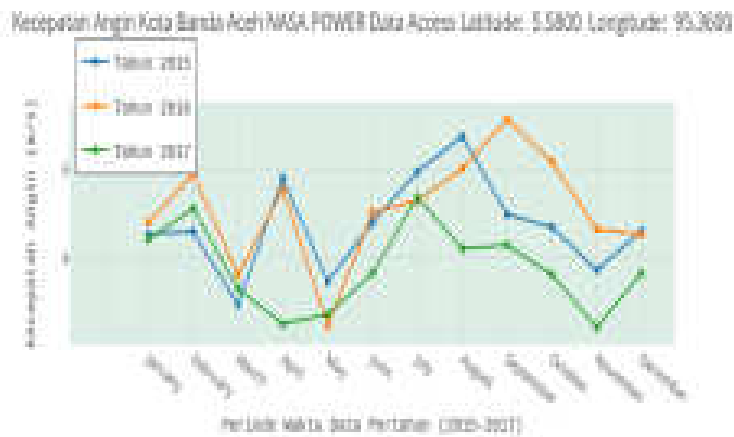

Gambar 2. Gafik data kecepatan angin rata-rata tahunan periode tahun 2015- 2017

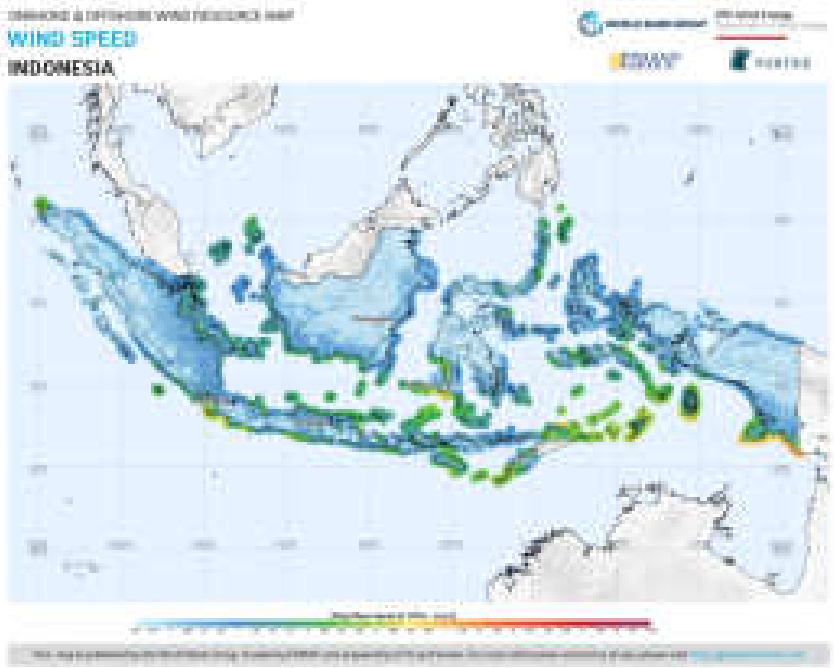

Gambar 3. Potensi Kecepatan Angin Wilayah Indonesia [3]

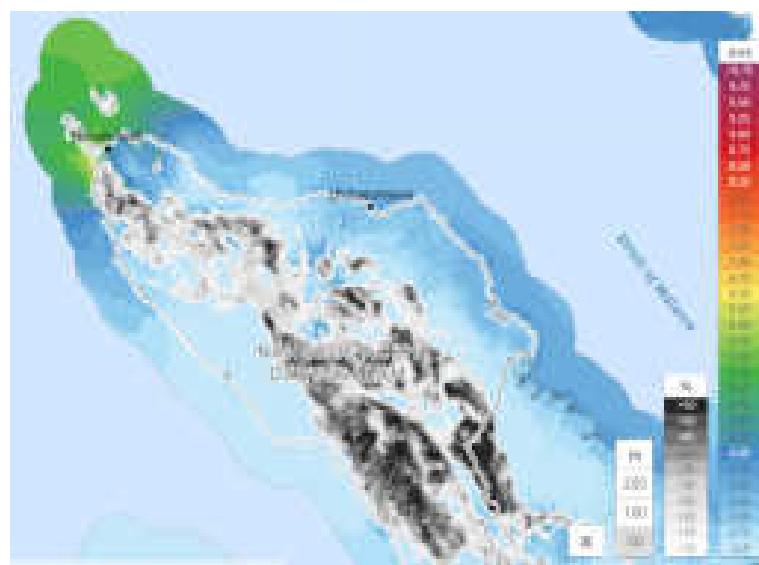

Gambar 4. Potensi kecepatan angin kota Banda Aceh [4]

Turbin angin jenis Darrieus di anggap memiliki kemampuan yang paling cocok untuk aplikasi pada kecepatan angin yang rendah dan sensitivitas yang lebih rendah terhadap arah angin dibandingkan dengan Horizotal axis. Kemampuan self-starting turbin ini juga dapat beroperasi tanpa perlu penyesuaian arah angin. Hal ini yang membuat turbin ini ideal pada daerah perkotaan yang memiliki kecepatan angin yang rendah serta dapat bersinergi dengan infrastruktur bangunan kota.

Pembangkit energi terbarukan adalah solusi yang sedang digalakkan untuk mengganti sumber energi konvensional yang non terbarukan sebagai sumber daya listrik utama. Perubahan iklim global yang disebabkan oleh karbon dioksida dan sulfur yang merupakan dampak yang dihasilkan oleh pembangkit energi non terbarukan sebagai emisi dioksida yang 
dihasilkan[5]. Energi terbarukan dengan biaya rendah sangat efektif diterapkan, sehingga terbebas dari emisi non karbon serta ramah lingkungan.

Beberapa bentuk energi terbarukan antara lain energi surya, pasang surut, biomassa, biofuel, panas bumi dan angin. Turbin angin telah banyak digunakan dan dianggap sebagai sumber energi sebagai pembangkit tenaga listrik alternatif [6].

Dalam ilmu fisika yang mendasari turbin angin Darrieus diklasifikasikan menjadi turbin berbasis gaya lift dan turbin berbasis drag merupakan implementasi dari turbin savonius. Pada awal tahun 1920-an Bezt telah melaporkan secara teori tidak lebih dari 16/27 atau $59.3 \%$ daya angin yang dapat dimanfaatkan dari energi angin itu sendiri[7].

\section{Tinjauan Pustaka}

2.1. Modelling Aerodinamika dan Teori Turbin Angin Rotor Tegak

a. Modelling Aerodinamika.

Untuk mendesain turbin angin, konfigurasi airfoil pada rotor turbin adalah salah satu faktor yang paling penting untuk menghasilkan efesiensi maksimum yakni mengubah energi kinetik menjadi energi mekanik menggunakan rotor dan generator yang akan menghasilkan energi listrik.
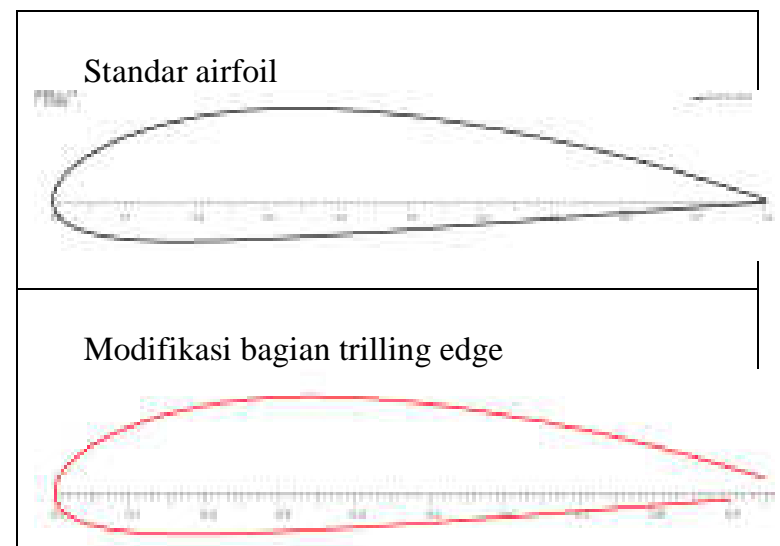

Gambar 5. NACA airfoil 4418 standart \& 4418 modifikasi (bagian trilling edge)

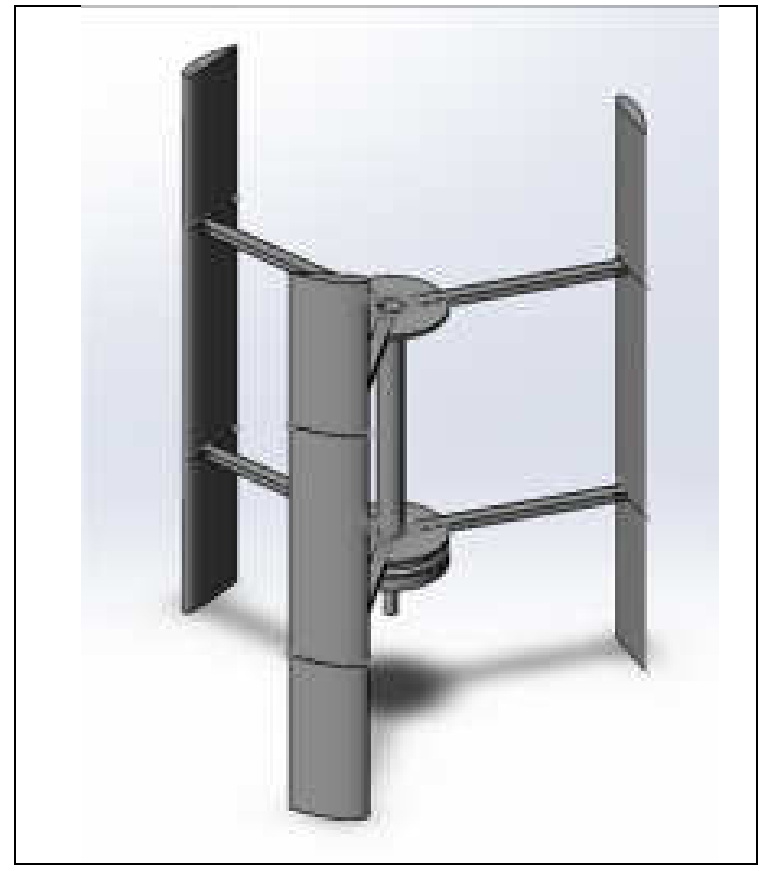

Gambar 6. Tampilan 3D desain rotor turbin angin vertikal

Sebuah rotor turbin di desain dan disimulasikan dengan menggunakan airfoil yang berbeda untuk menguji Power Coefisient $(\mathrm{Cp})$ terhadap tip speed rasio (TSR). Simulasi menggunakan tiga bilah rotor turbin yang berbeda seperti di tunjukkan pada Tabel 1 dan desain airfoil. Berdasarkan Gambar 1, ditemukan bahwa profil trilling edge memainkan peranan penting dalam meningkatkan kinerja turbin angin vertical pada rasio tip yang relatif rendah. Ketebalan airfoil juga dapat meningkatkan kinerja turbin secara signifikan[8].

Simulasi dilakukan menggunakan software Qblate untuk membandingkan kinerja dari keduanya yaitu NACA (National Advisory Committee on Airfoil) empat digit asimetris 4418 standart dan 4418 yang dimodifikasisehingga memiliki kinerja yang baik antara cooeffesient lift dan drag walaupun keduanya memiliki torsi yang rendah. Konfigurasi airfoil dari keduanya diilustrasikan pada Gambar 5.

Meninjau pada simulasi yang telah dilakukan oleh Paraschivoiu model double multiple streamtube untuk kecepatan induksi yang bervariasi, karena memiliki bentuk toposkien. Berbeda dengan turbin Darrieus yang tidak memiliki variasi kecepatan induksi, pada rotor sudut theta memiliki kondisi elemen yang normal pada bidang xy disamakan dengan nol.

Bagian picth dari vertikal turbin angin diasumsikan tetap dengan cord (C) yang bersinggungan dengan rotasi lingkaran (jalur rotasi penerbangan rotor) itu adalah sama dengan nol. 


\subsection{Daya Yang Tersedia di Udara}

Angin merupakan udara yang bergerak secara acak dengan massa udara. Ketika masa udara memiliki kecepatan, angin yang dihasilkan memiliki energi kinetik (KE) yang sebanding dengan massa udara dan kuadrat dengan kecepatan udara, yaitu $=(1 / 2) \mathrm{x}$ (kecepatan udara $)^{2} \mathrm{x}$ (massa udara). Persamaan energi kinetik melewati area dalam satuan waktu [9]:

$$
\mathrm{Pw}=1 / 2 \rho A v \mathrm{xv}^{2}=1 / 2 \rho A v^{3}
$$

Dimana $\rho$ adalah densitas udara $1.22 \mathrm{~kg} / \mathrm{m}^{3}$, v kecepatan angin, A area yang dilewati angin, $\rho \mathrm{Av}$ massa udara yang dilewati angin dalam satuan waktu, dan $\mathrm{Pw}$ merupakan daya yang tersedia pada angin untuk diektraksi oleh turbin angin. Hanya sebagian kecil dari Pw dapat benar-benar diekstraksi. Meskipun sebagian penelitian menggunakan distribusi kecepatan angin sederhana dan parameter kecepatan angin ratarata.

Sweapt Area merupakan area sapuan turbin angin di udara yang tergantung dari jenis turbin angin, baik jenis sumbu horizontal yang berbentuk lingkaran, maupun sumbu vertikal lurus, yang berbentuk persegi panjang tergantung pada konfigurasi rotor dan sweapt area dapat dihitung dengan:

$$
\mathrm{A}=\mathrm{D} . \mathrm{h}
$$

dimana A adalah sweapt area (area sapuan turbin), D adalah diameter dan $\mathrm{h}$ merupakan tinggi rotor turbin.

Area sapuan membatasi volume udara yang lewat oleh turbin angin, rotor mengubah energi yang tersimpan oleh angin dalam gerakan rotasinya, sehingga semakin besar daerah, keluaran daya semakin besar dalam kondisi angin yang sama, daya berbanding lurus terhadap sweapt area.

2.3 Analisis Teori Rotor Turbin Angin Darriouss Tipe

\section{Rotor Tegak}

Aerodinamika turbin angin Darrious sumbu vertical jauh lebih komplek dan rumit dibandingkan turbin angin konvensional sumbu horizontal, hal ini karena memiliki sumbu rotasi tegak lurus dengan pola aliran udara yang mendekat. Kecepatan angin mengalir pada hulu (upstreem) dan hilir (downstream) disisi turbin tidak konstan. Karakteristik aerodinamis pada rotor turbin jenis vertical ditunjukkan pada Gambar. 6 . Komponen kecepatan angin relative (Vr) diperoleh dari komponen kecepatan angin lembut dan kecepatan angin normal sebagai berikut[10] :

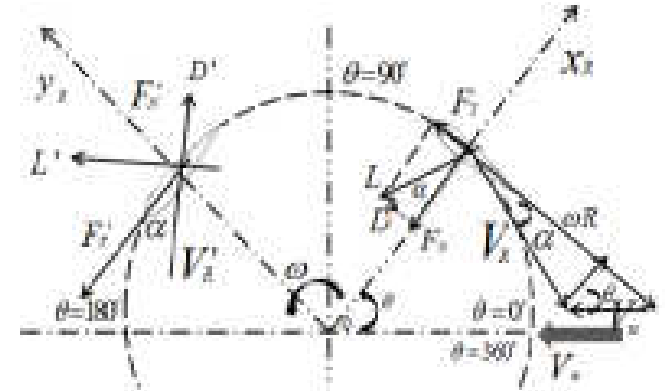

Gambar 7. Aliran Kecepatan Angin rotor turbin angin Darrious tipe Straight [10]

$$
V_{R}=\sqrt{\left(V_{a} \sin \theta\right)^{2}}\left(V_{a} \cos \theta+\omega R\right)^{2}
$$

Dimana $V_{a}$ induksi kecepatan angin, merupakan difinisi sebagai kecepatan axial aliran melalui rotor, sudut $\theta$ adalah Azimuth dan $\omega$ kecepatan rotasi, $R$ merupakan radius turbin. Ekspetasi dari radius rotor kecepatan tip terhadap kecepatan angin tip speed rasio[11] :

$$
\begin{aligned}
& T S R=\frac{v_{\text {Tip }}}{v_{\text {wind }}}=\frac{\omega \cdot R_{\text {Tip }}}{v_{\text {wind }}} \\
& C p=Q \omega /\left(1 / 2 \rho V^{3} A\right)
\end{aligned}
$$

Dimana :

$\omega$ kecepatan rotasi pada rotor $(\mathrm{rad} / \mathrm{sec})$,

$\mathrm{Q}$ torsi rotor,

$\rho$ densitas udara,

A merupakan swept Area turbin angina.

Soliditi merupakan area yang menutupi kawasan rotor turbin angin vertikal didefinisikan sebagai :

$$
\tau(\text { solidity })=\frac{N C}{D}
$$

Dimana solidity merupakan fungsi dari $\mathrm{N}$ jumlah rotor, $\mathrm{C}$ adalah panjang cord serta $\mathrm{D}$ diameter turbin angin. Merujuk dari Gambar 2.3, untuk sudut alpa atau Angle of attack (AoA) di ekspektasikan dengan :

$$
\tan \alpha=\frac{V_{a} \sin \theta}{V_{a} \cos \theta+\omega R}
$$

Persamaan non dimensional

$$
\tan \alpha=\frac{\frac{V a}{V \infty} \sin \theta}{\frac{V a}{V \infty} \cos \theta+\frac{\omega R}{V \infty}}
$$

Maka sudut alpha (AoA) adalah

$$
\alpha=\tan ^{-1}\left[\frac{a \sin \theta}{a \cos \theta+\lambda}\right]
$$


Koefisien gaya normal dan koefisien gaya tangensial dapat diekpresikan sebagai:

$$
\begin{aligned}
& C_{n}=C_{L} \operatorname{Cos} \alpha+C_{D} \operatorname{Sin} \alpha \\
& C_{t}=C_{L} \operatorname{Sin} \alpha-C_{D} \operatorname{Cos} \alpha
\end{aligned}
$$

dimana $\mathrm{C}_{\mathrm{L}}$; koefisien lift, $\mathrm{C}_{\mathrm{L}}$; koefisien Drag serta $\alpha$ merupakan sudut Attack (AoA).

Gaya Dorong sesaat pada satu rotor airfoil tunggal pada sudut $\theta$ tertentu.

$$
\begin{aligned}
& F_{N}=1 / 2 \rho V_{R}^{2}(h c) C_{n} \\
& F_{T}=1 / 2 \rho V_{R}^{2}(h c) C_{t}
\end{aligned}
$$

dimana $\mathrm{h}$ merupakan tinggi/bentang rotor turbin dan $\mathrm{c}$ adalah panjang Cord airfoil

Sesuai dengan referensi Gambar 3. Kemudian gaya dorong (trust force $\mathrm{T}_{\mathrm{i}}$ ) yang merupakan elemen pada turbin angin di satu rotor pada turbin pada aliran ditulis sebagai:

$$
T_{i}=1 / 2 \rho V_{R}^{2}(h c)\left(C_{t} \cos \theta-C_{n} \sin \theta\right)
$$

$\mathrm{h}$ adalah tinggi rotor dan c (panjang cord)

Sedangkan gaya tangensial merupakan penggerak rotasi rotor turbin yang menghasilkan torsi sesaat pada airfoil rotor tunggal pada sudut tetha tertentu adalah sebagai berikut:

$$
\begin{aligned}
& \mathrm{Q}_{\mathrm{i}}=\mathrm{F}_{\mathrm{t}} \mathrm{R} \\
& Q_{i}=1 / 2 \rho V_{R}{ }^{2}(h c) C_{t} R
\end{aligned}
$$

Torsi sangat penting untuk mengerakkan generator dan menghasilkan listrik.

Pemodelan aerodinamika mengunakan system Double multiple Streamtube (DMS) model dengan menggunakan software Qblade akan menghasilkan serta memprediksi secara akurat dinamika bangun yang dihasilkan oleh rotor turbin angin. Secara garis besar untuk model akan dijelaskan di bawah ini, akan tetapi untuk pemahaman akan mengacu pada referensi asli untuk deskripsi serta metode yang lebih rinci.

\section{Metode Penelitian}

Pada penelitian ini, mengevaluasi kinerja picth tetap pada turbin angin Darrieus Vertikal mengunakan tiga bilah baling-baling rotor turbin angin dengan menggunakan airfoil asimetris NACA 4418 dan NACA 4418 modifikasi bagian trilling edge. Model DMS serta analisis dengan aliran 2D Unsteady mengunakan DMS Qblade. Algoritma ini juga telah di validasi oleh penelitian dari Paraschivoiu[12][13].
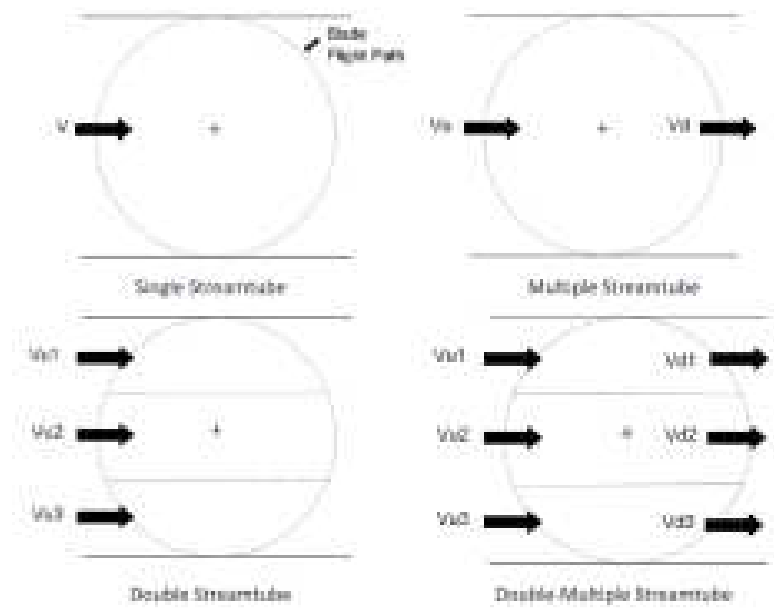

Gambar 8. Model analisis streamtube untuk turbin angin Darrieus vertikal[12].

Model ini menggunakan teori actuator disk dua tahap, tahap pertama dikenal dengan upstream dan tahap kedua disebut downstream untuk tiap bagian pada rotor. Teori ini menjelaskan actuator disk diwakili sebagai rotor turbin angin yang menciptakan diskontinuitas didalam tabung udara (streamtube) yang mengalir melalui turbin. Tekanan menyebabkan deselerasi yang menghasilkan kecepatan yang diinduksi. Factor induksi ditentukan dengan 0.33 [14] atau $1 / 3$ dari nilai trust dengan nilai normal induksi dengan parameter pada tabel 2 .

\begin{tabular}{l|l}
\hline Parameter & Nilai \\
\hline Diameter Turbin (meter) & $1.1 \mathrm{~m}$ \\
\hline Tinggi rotor turbin (meter) & $1.4 \mathrm{~m}$ \\
\hline Sweap Area & 1.6 \\
\hline N (Jumlah rotor) & 3 \\
\hline NACA airfoil & $4418($ modifikasi) \\
\hline Panjang Cord & $0.160 \mathrm{~m}$ \\
\hline P (Densitas udara & $1.2 \mathrm{~kg} / \mathrm{m}^{3}$ \\
\hline TSR (tip speed rasio) & $1.2-3.5$ \\
\hline Reynold number (Re) & 139000 \\
\hline Induction factor & 0.33 \\
\hline Pitch Angle (tetap) & $0^{\circ}$ \\
\hline V (Kecepatan angin) & $4.35 \mathrm{~m} / \mathrm{s}$ \\
\hline
\end{tabular}

Tabel 2. Nilai parameter simulasi rotor turbin vertikal.

Diameter dan tinggi turbin serta nilai sweapt area merupakan hasil kalkulasi untuk menghasilkan sekurangnya untuk menghasilkan daya di asumsikan sebesar $200 \mathrm{~W}$, parameter pada tabel tersebut merupakan dasar melakukan simulasi sesuai dengan Gambar 8 untuk menghitung nilai dengan metode model DMS. 


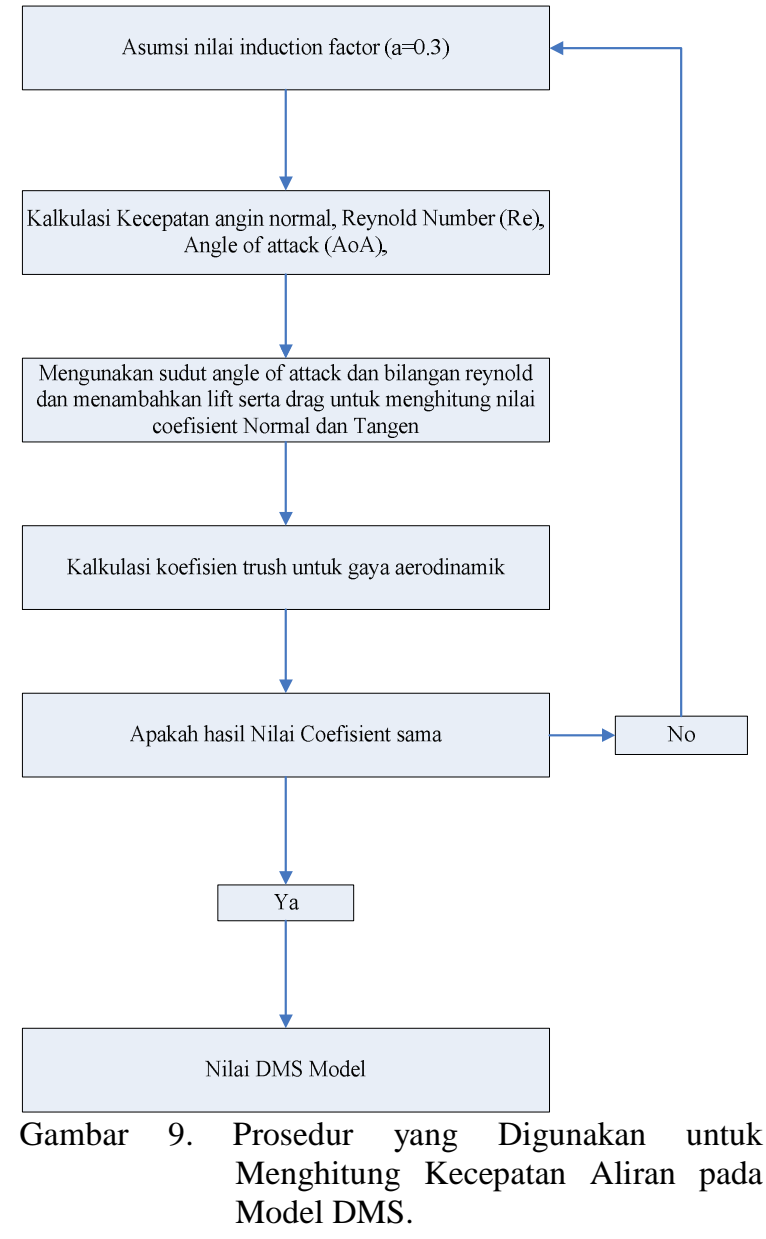

\section{Hasil dan Pembahasan}

Kinerja turbin adalah merupakan Coefficient Power $(C p)$ diperoleh dari rasio daya turbin terhadap daya yang tersedia di udara. Pendekatan yang terbaik dari kinerja turbin angin dapat di amati dari nilai koefisien daya terhadap tip speed rasio. Gambar 4.3 dan Gambar 4.5 yang menunjukkan kinerja power koefisien $(\mathrm{Cp})$ dan kurva daya, yang merupakan hasil modifikasi airfoil yang dapat dilihat pada Gambar 10 . Perbandingan $\mathrm{Cl} / \mathrm{Cd}$ kedua airfoil dan Gambar 11 menunjukkan tampilan 2D AoA yang sudut theta pada tip speed rasio rendah yang di targetkan dengan kecepatan angin rata-rata $4.35 \mathrm{~m} / \mathrm{s}$ prosedur dilakukan sesuai alur dari iterasi pada Gambar 3.2.

Hasil tersebut merupakan rangkaian yang dilakukan pada prosedur iteratif sesuai dengan diagram yang di tunjukkan pada Gambar 12. Nilai TSR terendah akan di targetkan pada simulasi ini, hal ini disebabkan karena rendahnya kecepatan angin terhadap energi yang diamati di Banda Aceh.
Sebagai catatan bahwa simulasi ini memperhitungkan berbagai faktor interferensi dalam fungsi sudut Azimuth namun tidak memperhitungkan variasi kecepatan aliran vertikal, karena sifat dari turbin vertikal jenis rotor tegak.

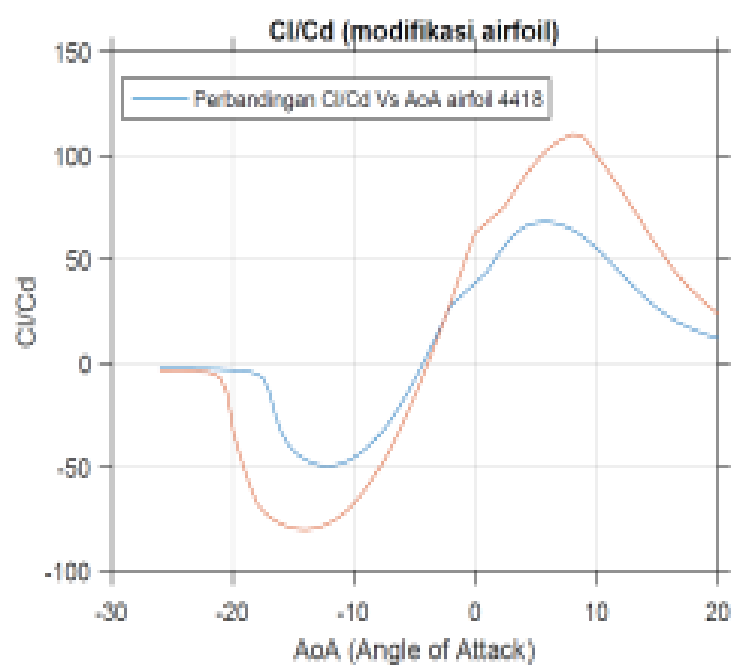

Gambar 10. Perbandingan Coefficient Lift/ Coeffecient Drag antara Airfoil 4418 telah dimodifikasi

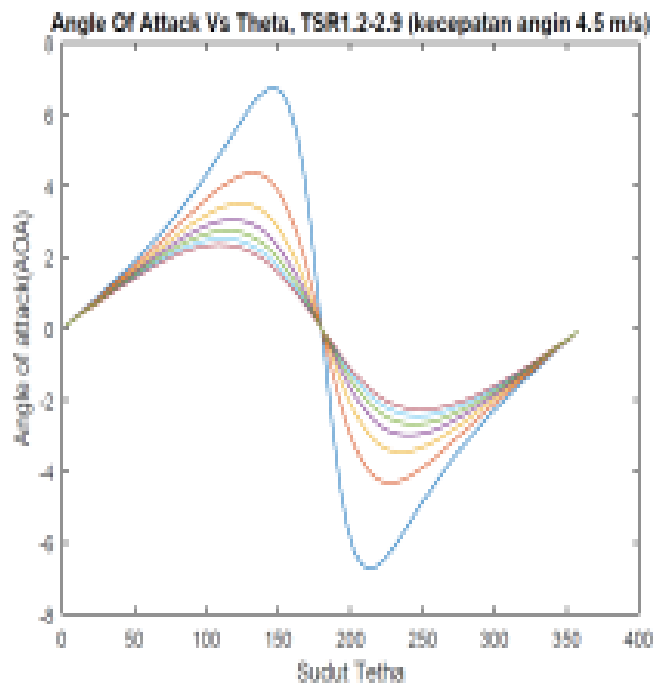

Gambar 11. Grafik 2D Sudut Alpha terhadap Sudut theta efek variasi TSR 


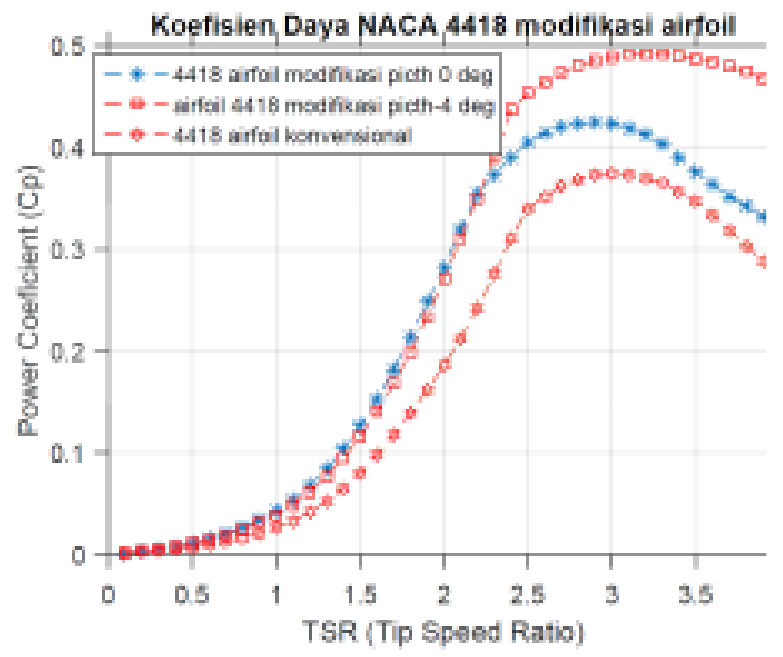

Gambar 12. Perbandingan Power Coefficient antara airfoil 4418 telah Dimodifikasi \& airfoil 4418 Konvensional.

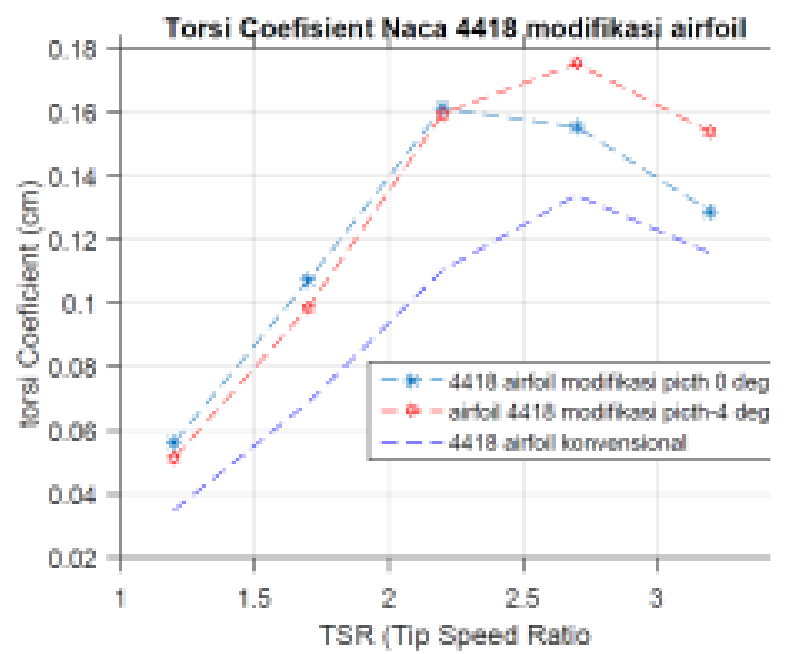

Gambar. 13. Perbandingan koefisien torsi dengan modifikasi NACA airfoil

Pada Gambar 13 dengan pitch tetap yakni $0^{\circ}$ dan pada line merah kotak dilakukan perubahan nilai pitch $-4^{\circ}$,menunjukkan bahwa perbandingan nilai koefisien daya $(\mathrm{Cp})$ yang dihasilkan oleh NACA airfoil 4418dan airfoil yang telah di modifikasi bagian trillingnya, dengan menghilangkan $12^{\circ}$ modifikasi pada bagian trilling edge dihilangkan. Hasil menunjukkan performa yang lebih baik dari bentuk aslinya yang mampu bekerja pada tip speed rasio (TSR) yang lebih rendah. $\mathrm{Cp}$ diperoleh dari rasio daya rotor turbin angin dan dimodelkan dengan daya angin yang tersedia.

Kecepatan angin di Banda Aceh berkisar $4.35 \mathrm{~m} / \mathrm{s}$ meskipun kenyataan kecepatan angin bisa melebihi, namun data mengambil acuan di range tersebut sesuai dengan data NASA data access pada koordinat kota
tersebut.Maka dengan menggunakan rentang tersebut dapat diamati sesuai dengan gambar.4.5 dengan perubahan nilai daya mengikuti meningkatnya (kuadrat) kecepatan angin dengan nilai $\mathrm{Cp}$ yang konstan.

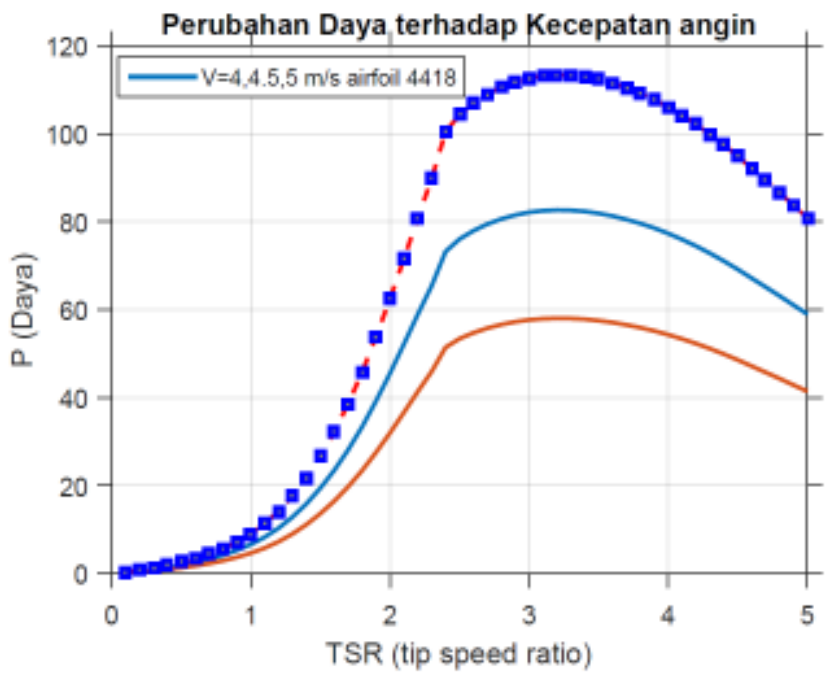

Gambar 14. Perubahan daya yang di hasilkan turbin angin sesuai dengan perubahan kecepatan angin 4,4 .dan $5,5 \mathrm{~m} / \mathrm{s}$.

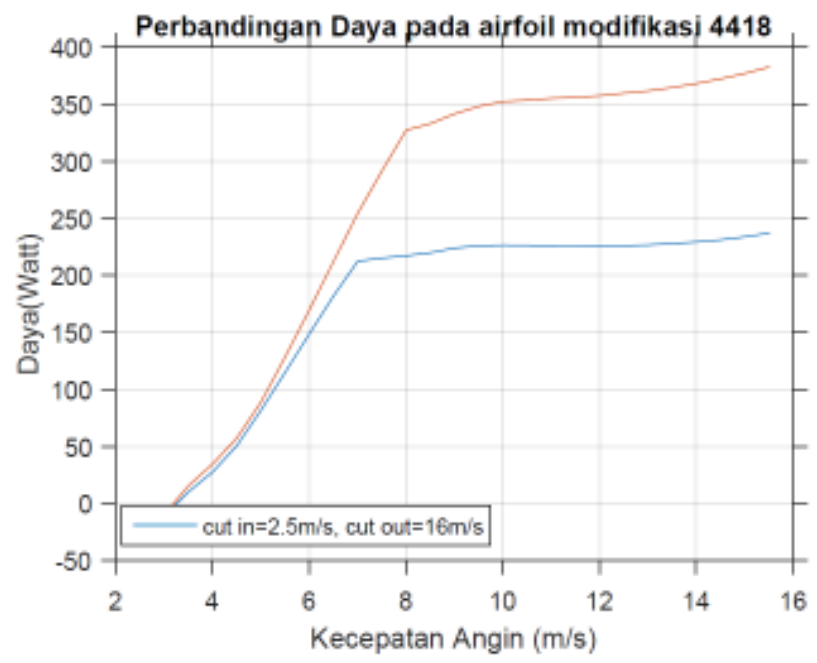

Gambar 4.6 Hasil perbandingan kurva daya turbin angin air foil standar vs modifikasi airfoil NACA 4418

\section{Kesimpulan}

Berdasarkan prinsip momentum model DMS yang memperhitungkan faktor induksi pada aliran angin dan arah angin dari rotor turbin Darrieus serta menunjukkan pendekatan yang baik untuk memodelkan pada model rotor yang lurus (tegak). Sebuah perbaikan telah 
disimulasikan menggunakan Qblade pada modifikasi airfoil dari bentuk konvensionalNACA airfoil4418 menjadi bentuk asimetris pada NACA airfoil4418. Modifikasi dilakukan dengan mengubah serta menghilangkan pada bagian trilling $10^{\circ}$ terbukti mampu meningkatkan nilai koefisien daya $(\mathrm{Cp}) 26 \%$ dengan nilai puncak $43 \%$ (sebelumnya dengan bentuk airfoil konvensional dengan nilai Cp 19\% dengan nilai puncak 37\%). Hasil modifikasi juga mampu bekerja pada rasio tip yang relatif rendah dengan nilai TSR 1.9. Dengan meningkatnya nilai $\mathrm{Cp}$ maka efesiensi maksimum dapat didekati, hal ini juga terlihat dengan peningkatan daya yang dihasilkan.

\section{Daftar Pustaka}

[1] B. Shahizare, W. T. Chong, S. Tabatabaeikia, N. Izadyar, and A. Esmaeilzadeh, "Novel investigation of the different Omni-directionguide-vane angles effects on the urban vertical axis wind turbine output power via three-dimensional numerical simulation," ENERGY Convers. Manag., vol. 117, pp. 206-217, 2016.

[2] "NASA Prediction of Worldwide Energy Resource (POWER)." [Online]. Available: https://power.larc.nasa.gov/cgibin/v1/DataAccess.py?\&request=execute\&identif ier=SinglePoint $\&$ parameters $=W S 10 M \&$ startDate $=20150101 \&$ \&ndDate $=20171231 \&$ userCommunit $\mathrm{y}=$ SSE\&tempAverage $=$ DAILY\&outputList $=$ ASC II \&lat $=5.5800 \&$ lon $=95.3600$.

[3] "2025, Pemerintah Targetkan 1,8 GW Pembangkit Tenaga Bayu Terbangun di Indonesia," KEMENTERIAN ENERGI DAN SUMBER DAYA MINERAL. [Online]. Available: https://www.esdm.go.id/id/media-center/arsipberita/2025-pemerintah-targetkan-18-gwpembangkit-tenaga-bayu-terbangun-di-indonesia.

[4] "Global Wind Speed Atlas," online avelable, 2017. [Online]. Available: https:/globalwindatlas.info/area/Indonesia.

[5] A. Grimaud and L. Rougé, "Polluting nonrenewable resources, innovation and growth: Welfare and environmental policy," Resour. Energy Econ., vol. 27, no. 2, pp. 109-129, 2005.

[6] I. Kubiszewski, C. J. Cleveland, and P. K. Endres, "Meta-analysis of net energy return for wind power systems," Renew. Energy, vol. 35, no. 1, pp. 218-225, 2010.

[7] KarlH.Bergey, "The Lanchester-Betz Limit," $J$ Energy, vol. 3, no. 6, pp. 382-385, 1979.

[8] K. M. Almohammadi, D. B. Ingham, L. Ma, and M. Pourkashanian, "2-D-CFD analysis of the effect of trailing edge shape on the performance of a straight-blade vertical axis wind turbine," IEEE
Trans. Sustain. Energy, vol. 6, no. 1, pp. 228-235, 2015.

[9] A. L. Manwell, J.F. McGowan, J.G. Rogers, Wind energy explained - theory, design and application, vol. 2. 2009.

[10]F. Kanyako and I. Janajreh, "Vertical Axis Wind Turbine Performance Prediction for Low Wind Speed Environment," Innov. Technol. Conf., pp. 110, 2014.

[11]P. C. Klimas and M. H. Worstell, "Effects of blade preset pitch/offset on curved-blade Darrieus vertical axis wind turbine performance," Sand-811762. p. 15, 1981.

[12]I. Paraschivoiu, O. Trifu, and F. Saeed, "HDarrieus Wind Turbine with Blade Pitch Control," Int. J. Rotating Mach., vol. 2009, no. May 2009, pp. 1-7, 2009.

[13]H. Beri and Y. Yao, "Double Multiple Streamtube Model and Numerical Analysis of Vertical Axis Wind Turbine," Energy Power Eng., vol. 03, no. 03, pp. 262-270, 2011.

[14] A. P. Schaffarczyk, "Introduction to wind turbine engineering," 2014, p. 130. 
